\title{
HAEMATOLOGICAL CHARACTERISTICS ASSOCIATED WITH PARASITISM IN MULLETS, MUGIL PLATANUS GÜNTHER, FROM THE ESTUARINE REGION OF CANANÉIA, SÃO PAULO, BRAZIL
}

\author{
Maria José Tavares Ranzani-Paiva ${ }^{1}$ \\ Carlos Massatoshi Ishikawa ${ }^{1}$ \\ Benedicto do Espírito-Santo de Campos ${ }^{2}$ \\ Augusta Cocuzza das Eiras ${ }^{1}$
}

\begin{abstract}
This study involved 344 Mullets, Mugil platamus Günther, 1880, captured in the estuarine region of Cananeia, São Paulo, Brazil $\left(25^{\circ} 00^{\prime} \mathrm{S}, 47^{\circ} 55^{\prime} \mathrm{W}\right)$. The following data were recorded for each fish: total weight, total length, haemoglobin ratio $(\mathrm{Hb})$, haematocrit $(\mathrm{Ht})$, erythrocyte count $(\mathrm{Er})$, differential leucocyte count (lymphocytes, monocytes, neutrophils, basophils and "other cells") and haematometric indices; MCV, MCH, and MCHC. The sex and stage of gonadal maturity (undifferentiated, juvenile, resting, maturing, mature, and spent) were determined by macroscopical inspection of the gonads. Parasitological inspections revealed the following infestations: Gills - Trichodinidae, Monogenea, Copepoda, and Hirudinea. Liver: cysts of Digenea. Intestine: Nematoda, Digenea and Acanthocephala. Blood: Trypanosoma sp. and Haemogregarina sp. Analysis of variance was done to evaluate how far blood and gill parasitism had any effect on total length, total weight, the biological condition factor or the measured blood parameters. Significant differences were found for the haematocrit (infested versus noninfested by Trichodinidae) and for MCHC (infested versus noninfested by Trichodinidae and Copepoda). No differences were found with regard to leucocytes.

KEY WORDS. Mugil platanus, hematology, parasitism, mullet, estuarine region
\end{abstract}

The simplicity of determining certain blood parameters is probably responsible for the rise in the use of haematology as a tool for testing of health problems in fish, even those not usually directly associated with the blood.

In medicine, haematological techniques are used for the following three objectives (listed in order of frequency as reported by DAVIDSON \& HENRY 1969 apud BLAXHALL 1972): 1) Differentiating normal from abnormal blood, 2) Diagnosis of disease or abnormality, 3) Detailed studies in haematology.

Pathological conditions in fish are manifested in the form of changes in the behavior (symptoms) and/or in the integrity of the tissues (lesions), leading to a decrease in weight gain and often, death (ROBERTS 1981).

1) Seção de Aquicultura, Divisão de Pesca Interior, Instituto de Pesca, CPA, SAA. Avenida Francisco Matarazzo 455, 05031-900 São Paulo, São Paulo, Brasil.

2) Instituto de Zootecnia, CPA, SAA. Rua Heitor Penteado 56, Caixa Postal 60, 13460-000 Nova Odessa, São Paulo, Brasil. 
According to TATCHER (1981), many parasites can live in a host, sometimes causing damage, sometimes not. Therefore, it is necessary to associate changes in haematological parameters with various parasitoses to establish a data base, as ROBERTS (1981) infers, in order to allow precise diagnoses which will reliably guide the implementations of treatment or preventive measures, which are indispensable in fish farming.

Despite of the potential and present value of mullet in brazilian aquaculture (SCORVO FILHO et al. 1992), information about diseases been confined to isolated studies concerned with occurrence of parasites (PAPERNA \& LAHAV 1974; PAPERNA \& OverstreET 1981; CONROY \& CONROY 1984; FACCHINI 1987). A success in aquaculture is keeping health fishes, resistant, to diseases and hendling. Fish health maintenance is arising in economic impotance. This requires diagnoses and fight against sickness, important step for good quality in research and to fish culture (KINKELIN et al. 1991).

The aim of the present study is to determine changes that occur in the blood in association with parasitism, allowing for more intensive production of this species on fish farms.

\section{MATERIAL AND METHODS}

Mullets, Mugil platanus Günther, 1880, were collected every month from July 1988 to June 1989 from the estuarine region of Cananeia, São Paulo, Brazil $\left(25^{\circ} 00^{\prime} \mathrm{S}, 47^{\circ} 55^{\prime} \mathrm{W}\right)$. Those with a total length of more than $30 \mathrm{~cm}$ were captured in fixed fence-traps in the region between the delta and the outlying islands and those smaller individuals were captured with throw nets in lagoons of the Comprida and Cardoso islands, where salinity is lower than in the first region.

The fish were brought to the laboratory of the Oceanographic Institute o the University of São Paulo in Cananeia, where they were kept in 1000-liter asbestosreinforced concrete tanks, the water being continuously aerated by means of compressed air. The blood was sampled soon after the fish were put into the tanks.

The blood was withdrawn by heart puncture, with disposable 3-ml syringes with heparinized $8 \times 25$ needles, and used for the following analysis: haematocrit (Ht) by the microhaematocrit method (GOLDFARB et al. 1971); haemoglobin ratio $(\mathrm{Hb})$ by the cyanometahaemoglobin method (COLLIER 1944); erythrocyte or total cell count (Er) done in a Neubauer chamber and using Hayen's solution as the diluent; haematimetric indexes (MCV, $\mathrm{MCH}$ and $\mathrm{MCHC}$ ) using the formulas of WINTROBE (1934); differential leucocyte count, using smears stained by Leshman's stain.

After the blood was drawn, each fish was weighed (Wt - total weight in grams), measured (Lt - total length in centimeters) and then killed by decerebration, introducing a knife in its brain.

A ventral-longitudinal cut was made from the anus to the heart cavity, to expose the organs. The sex was determined by macroscopic inspection of the gonads, that were cut out and weighed (Wg - gonad weight in grams). The results of $\mathrm{Lt}, \mathrm{Wt}$, and $\mathrm{Wg}$ were used to calculate the allometric condition factor $(\mathrm{K})$ following ISSAC-NAUM \& VAZZOLLER (1983). 
Each fish used for haematological studies was also analysed parasitologically, being liver, gills and intestine removed. Liver fragments were squashed between slide and cover slide, and inspected in a light microscope. Scrapings were taken from the gills, and also inspected between slide and cover slide in a light microscope. The entire gills were removed, and inspected though a stereomicroscope, the parasites being looked for along each gill arch, separating the lamellas. The intestine was opened longitudinally and examined under a stereomicroscope.

The parasites were removed and fixed in AFA or $70 \%$ ethyl alcohol depending on the taxonomic group, and identified to the lowest posible taxonomic level.

The blood parasites were detected during the differential leucocyte counts on the blood smears.

Statistical analysis were made considering the degree of parasitic infestation in each organ studied. For Copepoda the degree of infestation was classified from 0 to 2 . For all parasites a binary classification was used: either with (1) or without prasites( $(0)$, as that the number of infected fish was low, as was the number of parasites per fish.

To evaluate if the percentages of fish infested versus not infested bore any correlation to sex, the chi-square test was used following CosTA NETO (1977).

To establish if the type and degree of parasitic infestation bore any correlation to the haematological data, the computer program LSMLMW was used (HARVEY 1987), the analysis made by the least-squares method, due to the unequal number of fish in the subclasses.

\section{RESULTS AND DISCUSSION}

This study involved 344 mullets, Mugil platanus (144 males, 123 females, 1 hermaphrodite and 76 undifferentiated, this term being applied to those whose gonads were difficult to characterize macroscopically).

Parasites of the following taxonomic categories were found in the respective organs: Gills: Trichodinidae, Monogenea, Copepoda and Hirudinea. Liver: cysts of Digenea. Intestines: Nematoda and Acanthocephala. Blood: Trypanosoma sp. and Haemogregarina sp.

In about 20 fish, flagellate protozoans were found in the gills, identified as Cryptobia sp. The two mullets with the highest degree of infestation by this protozoan were captured in the same sample (June/1989) and didn't show anything special in terms of their blood characteristics, except for a readily apparent neutrophil ( 88.50 and $84.00 \%)$. However, this neutrophil couldn't be considered an indicator, in that there were other specimens that also showed a high percentage of neutrophils in the absence of this parasitosis.

For the test of correlation between the haematological and parasitic data, gill and blood parasites were considered, since according to TATCHER (1981), biological agents that attack the gills or simply attach themselves there can be considered pathogenic, even in the absence of any apparent pathogenic conditions. Any decrease in environmental dissolved oxygen will affect first those fish that have a 
problem of the respiratory system, especially the gills, whether in the wild or in captivity.

The percentages of infested fish, by sex, are given in table I. In this table it can be noted by the chi-square test that only for the haemogregarines there is a significant sex-correlated difference in the percentages of infested versus not infested fish ( $p \leq 0.01)$. It can also be noted that even though the difference is not statistically significant, the undifferentiated (captured in coastal lagoons) and the males always show a higher infestation percentage than the females, with the one exception of infestation by leeches, in which the females show the higher infestation percentage. Studies should be developed to better establish whether the higher percentage of infestation is really due to the sex of the fish, or to the environment they live in. It should be remembered that in the coastal lagoons the fish are more closely confined, a factor which may favour the transmission of parasites, especially those whose life cycle involves just one host species, as is the case in the present study.

The degree of infestation was not found to vary in any way according to the seasons of the year. The same was found by EIRAS (1987b) in relation to the infestation of Blennius pholis Linnaeus, 1758 by Haemogregarina bigemina (Laveran \& Mesnil, 1901). However, CARNEvia et al. (1988) studying Mugil liza Valenciennes, 1836 found a higher percentage of fish infested by Trichodinidae during the winter, in a context of high percentages all through the year.

Table I. Percentages of males, females and undifferentiated specimens infested by gi blood parasites: Mugil platanus from the estuarine region of Cananéia, São Paulo, Brazil.

\begin{tabular}{|c|c|c|c|c|c|c|c|c|c|}
\hline \multirow{2}{*}{$\begin{array}{l}\text { Parasites } \\
\text { (\%) }\end{array}$} & \multirow{2}{*}{$\begin{array}{l}\text { Infestation } \\
\text { level }\end{array}$} & \multicolumn{2}{|c|}{ Indifferentiated } & \multicolumn{2}{|c|}{ Male } & \multicolumn{2}{|c|}{ Female } & \multicolumn{2}{|c|}{ Total } \\
\hline & & $\%$ & $n$ & $\%$ & $n$ & $\%$ & $n$ & $\%$ & $\mathrm{n}$ \\
\hline \multirow{3}{*}{ Tripanosome } & Infested & $8.33^{\star}$ & 6 & $6.25^{\star}$ & 9 & $3.79^{\star}$ & 5 & 5.75 & 20 \\
\hline & Not infested & $91.67^{\star}$ & 6 & $93.75^{*}$ & 135 & $96.21^{*}$ & 127 & 94.25 & 328 \\
\hline & Total & & 72 & & 144 & & 132 & & 348 \\
\hline \multirow{3}{*}{ Haemogregarine } & Infested & 19.44 & 14 & 23.13 & 31 & 21.97 & 29 & 21.89 & 74 \\
\hline & Not infested & 80.55 & 58 & 76.87 & 103 & 78.03 & 103 & 78.11 & 264 \\
\hline & Total & & 72 & & 134 & & 132 & & 338 \\
\hline \multirow{3}{*}{ Trichodinidae } & Infested & 91.43 & 64 & 93.43 & 128 & 89.76 & 114 & 91.62 & 306 \\
\hline & Not infested & 8.57 & 6 & 6.57 & 9 & 10.24 & 28 & 8.38 & 28 \\
\hline & Total & & 70 & & 137 & & 127 & & 334 \\
\hline \multirow{3}{*}{ Monogenea } & Infested & 56.34 & 40 & 30.94 & 43 & 24.43 & 32 & 33.72 & 115 \\
\hline & Not infested & 43.66 & 31 & 69.06 & 96 & 75.57 & 99 & 66.28 & 226 \\
\hline & Total & & 71 & & 139 & & 131 & & 341 \\
\hline \multirow{4}{*}{ Copepoda } & Infestation level 1 & 67.60 & 48 & 51.08 & 71 & 40.46 & 53 & 50.44 & 172 \\
\hline & Infestation level 2 & 26.76 & 19 & 30.22 & 42 & 2.48 & 33 & 27.57 & 94 \\
\hline & Not infested & 5.63 & 4 & 18.71 & 26 & 34.35 & 45 & 21.99 & 75 \\
\hline & Total & & 71 & & 139 & & 131 & & 341 \\
\hline \multirow{3}{*}{ Hirudinea } & Infested & 4.23 & 3 & 15.83 & 22 & 24.43 & 32 & 16.72 & 57 \\
\hline & Not infested & 95.77 & 66 & 84.17 & 117 & 75.57 & 99 & 83.28 & 284 \\
\hline & Total & & 71 & & 139 & & 131 & & 341 \\
\hline
\end{tabular}

*. $p \leq 0.1 ;(n)$ number of individuals. 
In table II it can be noted that there was a significant correlation between infestation by Monogenea and total length, the infested fish being shorter. This significant difference, however, does not extend to total weight or (K). KHAN (1985), TORT et al. (1987), as well as PAVANELLI \& SANTOS (1991) found significant differences for the allometric condition factor $(\mathrm{K})$ for the fish they studied, in that the infested fish showed lower values for $\mathrm{K}$ than the noninfested ones.

Table II. Means $(\bar{X})$ and standard deviation $(S \bar{x})$ of the biological characteristics of Mugil platanus from the estuarine region of Cananéia, São Paulo, Brazil, according to the degree of the parasitic infestation.

\begin{tabular}{|c|c|c|c|c|}
\hline \multirow{2}{*}{$\begin{array}{c}\text { Parasites } \\
(\%)\end{array}$} & \multirow{2}{*}{$\begin{array}{l}\text { Infestation } \\
\text { level }\end{array}$} & \multirow{2}{*}{$\frac{\text { Total length }(\mathrm{cm})}{\bar{X} \pm S \bar{x}}$} & \multirow{2}{*}{$\frac{\text { Total weight (g) }}{\bar{x} \pm S \bar{x}}$} & \multirow{2}{*}{$\frac{\text { Condition factor }(K)}{\bar{X} \pm S \bar{x}}$} \\
\hline & & & & \\
\hline \multirow[t]{2}{*}{ Tripanosome } & Not infested & $42.88 \pm 1.07$ & $871.00 \pm 57.00$ & $7.81 \pm 0.21$ \\
\hline & Infestation level 1 & $40.96 \pm 1.83$ & $685.00 \pm 98.00$ & $7.29 \pm 0.35$ \\
\hline \multirow[t]{2}{*}{ Haemogregarine } & Not infested & $42,87 \pm 1.29$ & $849.00 \pm 69.00$ & $7.54 \pm 0.25$ \\
\hline & Infestation level 1 & $40.97 \pm 1.53$ & $708.00 \pm 82.00$ & $7.56 \pm 0.30$ \\
\hline \multirow[t]{2}{*}{ Trichodinidae } & Not infested & $41.99 \pm 1.33$ & $754.00 \pm 71.00$ & $7.45 \pm 0.26$ \\
\hline & Infestation level 1 & $41.85 \pm 1.41$ & $801.00 \pm 75.00$ & $7.65 \pm 0.27$ \\
\hline \multirow[t]{2}{*}{ Monogenea } & Not infested & $40.43 \pm 1.31$ & $726.00 \pm 70.00$ & $7.67 \pm 0.25$ \\
\hline & Infestation level 1 & $43.41 \pm 1.42^{\star *}$ & $831.00 \pm 76.00$ & $7.43 \pm 0.28$ \\
\hline \multirow[t]{3}{*}{ Copepoda } & Not infested & $43.33 \pm 1.98$ & $821.00 \pm 106.00$ & $7.48 \pm 0.39$ \\
\hline & Infestation level 1 & $41.15 \pm 1.23$ & $751.00 \pm 66.00$ & $7.45 \pm 0.24$ \\
\hline & Infestation level 2 & $41.28 \pm 1.41$ & $762.00 \pm 75.00$ & $7.72 \pm 0.27$ \\
\hline \multirow[t]{2}{*}{ Hirudinea } & Not infested & $41.09 \pm 1.23$ & $718.00 \pm 65.00$ & $7.39 \pm 0.23$ \\
\hline & Infestation level 1 & $42.75 \pm 1.54$ & $839.00 \pm 82.00$ & $7.71 \pm 0.30$ \\
\hline
\end{tabular}

${ }^{*} . p \leq 0.1$.

In the haematologic variables, (Tabs III, IV), significant differences ( $\mathrm{p} \leq 0.01$ ) were found only for the following: Both $\mathrm{Ht}$ and $\mathrm{MCHC}$ in relation to infested or not infested by Trichodinidae; $\mathrm{MCHC}$ in relation to infestation by Copepoda. There were no changes in blood characteristics for Mugil platanus infested by trypanosomes. This result is similar to that found by FACCHINI (1987), for Mugil liza captured in the same estuarine region of Cananeia.

The percentages of leucocytes showed no significant correlation with parasitic infestation (Tab. V). One should bear in mind that the high degree of variance in the data would make small actual correlations hard to detect. It should also be remembered that in this study neither the degree of infestation nor the length of time infested were substantially part of the data.

Studies of trypanosomes in mammals have clearly shown that some species are highly pathogenic while in other classes of vertebrates the infections appear benign except in a few isolated cases (KHAN 1985). In fish there are some reports of alteration in tissues, with emphasis on alterations in the blood (COTTRELL 1977; PULSFORD 1984). 
Table III. Means $(\bar{X})$ and standard deviation $(S \bar{x})$ of the blood characteristics of Mugil platanus from the estuarine region of Cananéia, São Paulo, Brazil, according to the degree of the parasitic infestation.

\begin{tabular}{|c|c|c|c|c|}
\hline \multirow[t]{2}{*}{$\begin{array}{c}\text { Parasites } \\
(\%)\end{array}$} & \multirow[t]{2}{*}{$\begin{array}{c}\text { Infestation } \\
\text { level }\end{array}$} & $\begin{array}{l}\text { Hematocrit } \\
(\%)\end{array}$ & \multirow{2}{*}{$\begin{array}{l}\begin{array}{l}\text { Haemoglobin concentration } \\
(\mathrm{g} / 100 \mathrm{ml})\end{array} \\
\overline{\mathrm{X}} \pm \mathrm{Sx}\end{array}$} & \multirow{2}{*}{$\begin{array}{c}\begin{array}{c}\text { Erythrocyte number } \\
\left(10^{4} / \mathrm{mm}^{3}\right)\end{array} \\
\bar{X} \pm S \bar{x}\end{array}$} \\
\hline & & $\bar{x} \pm S \bar{x}$ & & \\
\hline \multirow[t]{2}{*}{ Tripanosome } & Not infested & $33.04 \pm 1.06$ & $7.94 \pm 0.24$ & $303.62 \pm 9.20$ \\
\hline & Infestation level 1 & $34.02 \pm 1.82$ & $7.86 \pm 0.35$ & $314.64 \pm 16.52$ \\
\hline \multirow[t]{2}{*}{ Haemogregarine } & Not infested & $32.74 \pm 1.24$ & $7.94 \pm 0.28$ & $304.09 \pm 11.18$ \\
\hline & Infestation level 1 & $43.31 \pm 1.54$ & $7.86 \pm 0.35$ & $314.17 \pm 13.83$ \\
\hline \multirow[t]{2}{*}{ Trichodinidae } & Not infested & $35.30 \pm 1.31^{*}$ & $8.02 \pm 0.30$ & $313.74 \pm 11.91$ \\
\hline & Infestation level 1 & $31.75 \pm 1.38^{*}$ & $7.78 \pm 0.31$ & $304.51 \pm 12.43$ \\
\hline \multirow[t]{2}{*}{ Monogenea } & Not infested & $33.11 \pm 1.29$ & $7.75 \pm 0.29$ & $306.44 \pm 11.52$ \\
\hline & Infestation level 1 & $33.94 \pm 1.39$ & $8.05 \pm 0.32$ & $311.82 \pm 12.59$ \\
\hline \multirow[t]{3}{*}{ Copepoda } & Not infested & $32.19 \pm 1.98$ & $8.06 \pm 0.45$ & $302.33 \pm 18.04$ \\
\hline & Infestation level 1 & $33.85 \pm 1.22$ & $7.57 \pm 0.28$ & $307.64 \pm 10.90$ \\
\hline & Infestation level 2 & $34.54 \pm 1.39$ & $8.07 \pm 0.31$ & $317.41 \pm 12.51$ \\
\hline \multirow[t]{2}{*}{ Hirudinea } & Not infested & $32.42 \pm 1.17$ & $7.66 \pm 0.27$ & $299.44 \pm 10.62$ \\
\hline & Infestation level 1 & $34.64 \pm 1.57$ & $8.14 \pm 0.36$ & $318.82 \pm 13.62$ \\
\hline
\end{tabular}

${ }^{*} . p \leq 0.1$.

Table IV. Means $(\bar{X})$ and standard deviation $(S \bar{x})$ of the haematimetric indexes of Mugil platanus from the estuarine region of Cananéia, São Paulo, Brazil, according to the degree of the parasitic infestation.

\begin{tabular}{|c|c|c|c|c|}
\hline \multirow[t]{2}{*}{$\begin{array}{l}\text { Parasites } \\
(\%)\end{array}$} & \multirow[t]{2}{*}{$\begin{array}{l}\text { Infestation } \\
\text { level }\end{array}$} & $\begin{array}{l}\text { Mean corpuscular } \\
\text { volume }\left(\mu^{3}\right)\end{array}$ & \multirow{2}{*}{$\begin{array}{r}\begin{array}{c}\text { Mean corpuscular } \\
\text { haemoglobin }(\mu \mu \mathrm{g})\end{array} \\
\bar{x} \pm \mathrm{S}_{\bar{x}}\end{array}$} & \multirow{2}{*}{$\begin{array}{c}\begin{array}{c}\text { Mean corpuscular } \\
\text { haemoglobin concentration (\%) }\end{array} \\
\bar{x} \pm S \bar{x}\end{array}$} \\
\hline & & $\bar{x} \pm s \bar{x}$ & & \\
\hline \multirow[t]{2}{*}{ Tripanosome } & Not infested & $104.75 \pm 3.98$ & $28.02 \pm 0.96$ & $23.35 \pm 0.95$ \\
\hline & Infestation level 1 & $101.14 \pm 6.80$ & $26.09 \pm 1.64$ & $23.15 \pm 0.70$ \\
\hline \multirow[t]{2}{*}{ Haemogregarine } & Not infested & $105.04 \pm 4.64$ & $26.42 \pm 1.12$ & $24.46 \pm 0.65$ \\
\hline & Infestation level 1 & $98.42 \pm 5.76$ & $27.69 \pm 1.39$ & $23.70 \pm 0.80$ \\
\hline \multirow[t]{2}{*}{ Trichodinidae } & Not infested & $107.47 \pm 4.93$ & $26.99 \pm 1.19$ & $25.01 \pm 0.72^{*}$ \\
\hline & Infestation level 1 & $98.42 \pm 5.17$ & $27.12 \pm 1.25$ & $25.47 \pm 1.03^{\star}$ \\
\hline \multirow[t]{2}{*}{ Monogenea } & Not infested & $102.03 \pm 4.81$ & $26.94 \pm 1.16$ & $23.98 \pm 0.73$ \\
\hline & Infestation level 1 & $103.86 \pm 5.22$ & $27.18 \pm 1.26$ & $24.34 \pm 0.90$ \\
\hline \multirow[t]{3}{*}{ Copepoda } & Not infested & $98.21 \pm 7.41$ & $27.87 \pm 1.79$ & $22.63 \pm 0.64^{*}$ \\
\hline & Infestation level 1 & $105.74 \pm 4.55$ & $25.92 \pm 1.10$ & $24.15 \pm 0.73^{\star}$ \\
\hline & Infestation level 2 & $104.87 \pm 5.21$ & $27.37 \pm 1.26$ & $24.10 \pm 0.61^{*}$ \\
\hline \multirow[t]{2}{*}{ Hirudinea } & Not infested & $103.59 \pm 4.38$ & $26.60 \pm 1.06$ & $24.10 \pm 0.61$ \\
\hline & Infestation level 1 & $102.29 \pm 5.85$ & $27.51 \pm 1.41$ & $24.06 \pm 0.82$ \\
\hline
\end{tabular}

*. $p \leq 0.1$.

KHAN (1977) and KHAN et al. (1980) suggested that for Gadus morhua Linnaeus, 1758 and Myxocephalus octodecemspinosus Pinchuk, 1814, respectively, the anemia associated with trypanosome infestation is similar to the anemia that 
trypanosomes provoke in humans (JENNINGS 1976 apud PULSFORD 1984). LeTCH \& BALL (1979) suggested that the anemia in fish is more the result of repeated feeding of the leech (the vector), than a direct effect of the protozoan infestation.

Table V. Means $(\bar{X})$ and standard deviation $(S \bar{x})$ of the leucocyte percentages of peripherical blood of Mugil platanus from the estuarine region of Cananéia, São Paulo, Brazil, according to the degree of the parasitic infestation.

\begin{tabular}{|c|c|c|c|c|c|c|}
\hline \multirow{2}{*}{$\begin{array}{c}\text { Parasites } \\
(\%)\end{array}$} & \multirow{2}{*}{$\begin{array}{l}\text { Infestation } \\
\text { level }\end{array}$} & Lymphocytes & Monocytes & Neutrophils & Basophils & Other cells \\
\hline & & $\bar{x} \pm S \bar{x}$ & $\bar{x} \pm s \bar{x}$ & $\bar{x} \pm S \bar{x}$ & $\bar{x} \pm s \bar{x}$ & $\bar{x} \pm s \bar{x}$ \\
\hline \multirow[t]{2}{*}{ Tripanosome } & Not infested & $50.78 \pm 3.94$ & $3.71 \pm 1.02$ & $45.00 \pm 3.87$ & $0.67 \pm 0.12$ & $0.59 \pm 0.27$ \\
\hline & Infestation level 1 & $49.74 \pm 7.08$ & $5.07 \pm 1.83$ & $44.89 \pm 6.95$ & $0.80 \pm 0.21$ & $0.51 \pm 0.49$ \\
\hline \multirow[t]{2}{*}{ Haemogregarine } & Not infested & $44.86 \pm 4.67$ & $4.54 \pm 1.21$ & $49.98 \pm 4.59$ & $0.56 \pm 0.14$ & $0.77 \pm 0.32$ \\
\hline & Infestation level 1 & $55.66 \pm 6.03$ & $4.24 \pm 1.56$ & $36.91 \pm 5.92$ & $0.91 \pm 0.18$ & $0.33 \pm 0.41$ \\
\hline \multirow[t]{2}{*}{ Trichodinidae } & Not infested & $48.53 \pm 5.02$ & $4.77 \pm 1.30$ & $46.42 \pm 4.93$ & $0.73 \pm 0.15$ & $0.37 \pm 0.34$ \\
\hline & Infestation level 1 & $51.99 \pm 5.31$ & $4.01 \pm 1.37$ & $43.46 \pm 5.22$ & $0.74 \pm 0.16$ & $0.73 \pm 0.36$ \\
\hline \multirow[t]{2}{*}{ Monogenea } & Not infested & $47.02 \pm 5.36$ & $5.10 \pm 1.27$ & $41.22 \pm 4.80$ & $0.77 \pm 0.15$ & $0.48 \pm 0.34$ \\
\hline & Infestation level 1 & $54.51 \pm 6.56$ & $3.68 \pm 1.39$ & $48.67 \pm 5.27$ & $0.70 \pm 0.16$ & $0.62 \pm 0.37$ \\
\hline \multirow[t]{3}{*}{ Copepoda } & Not infested & $44.59 \pm 7.43$ & $4.33 \pm 1.92$ & $50.44 \pm 7.29$ & $0.92 \pm 0.22$ & $0.82 \pm 0.51$ \\
\hline & Infestation level 1 & $55.05 \pm 4.69$ & $3.91 \pm 1.21$ & $40.63 \pm 4.61$ & $0.72 \pm 0.14$ & $0.22 \pm 0.32$ \\
\hline & Infestation level 2 & $51.15 \pm 5.36$ & $4.93 \pm 1.39$ & $43.77 \pm 5.26$ & $0.57 \pm 0.16$ & $0.60 \pm 0.37$ \\
\hline \multirow[t]{2}{*}{ Hirudinea } & Not infested & $51.75 \pm 4.55$ & $4.17 \pm 1.18$ & $42.81 \pm 4.46$ & $0.69 \pm 0.14$ & $0.69 \pm 0.31$ \\
\hline & Infestation level 1 & $48.77 \pm 5.74$ & $4.62 \pm 1.49$ & $47.08 \pm 5.64$ & $0.78 \pm 0.17$ & $0.78 \pm 0.39$ \\
\hline
\end{tabular}

PULSFORD (1984), for Scyliorhinus canicola Linnaeus, 1758 infested by trypanosomes, found a reduction of $\mathrm{Ht}$ and $\mathrm{Er}$, and an increase in the number of leucocytes. KHAN (1985) experimentally infested Gadus morhua with Trypanosoma murmanensis Nikitin, 1927, finding alterations in blood characteristics; the $\mathrm{Ht}$ and the $\mathrm{Hb}$ being considerably lower in infested fish. Anemia was the most common aspect, positively correlated with parasitism. Anemic fish are lethargic.

In Mugil platanus no haemogregarines were found outside the erythrocytes, nor were there found any infested leucocytes. SMIRNOVA (1971), studying Cyprinus carpio Linnaeus, 1758 infested by haemogregarines found various phases of destruction of the erythrocytes in the blood of the outlying tissues of the infected fish. On certain occasions in infested fish it occurs that a high percentage of erythrocytes are destroyed by haemogregarines, so the capacity of the blood to carry out its respiratory function falls off considerably, which could be associated with the periodic deaths of carp. That author also verified a large quantity of basophils similar to monocytes but bigger and with small pseudopods, associated with parasitism. Some authors believe that part of the life cycle of haemogregarines occurs in the leucocytes (BECKER 1970; KIRMSE 1980). Infested lymphocytes show a larger number of pseudopods, which indicates an increase in cell physiology. PAPERNA \& OVERSTREeT (1981) hold that Haemogregarina mugili Carini, 1932 is, at least in the stages observed in Mugilideos, an infester of erythrocytes. Infested fish show a large quantity of pathological forms of the leucocytes in the blood of outlying tissues. 
According to EIRAS (1987a), there is circumstantial evidence of a relation between the degree of water pollution and the occurrence of haemogregarines in the blood of fish. Larger fish and thus older ones are also more infested. No change in any blood characteristic was found for fish infested by this parasite, as was the case of $M$. platanus.

The copepods found in the mullets attach themselves to the gills, depending on the species, in two ways: they hug a gill filament using their anterior antenna, or they have a proboscidis which they insert into a filament. The infested gills get white in their extremities due to the attachment systems of the parasites. These parasites belong to one of two families: Ergasilidae and Lernaeidae.

According to EINSZPORN-ORECKA (1970), the copepod parasites of fish cause damage to the respiratory epithelia of the gill filaments of the fish, mainly with their swimming appendages, parts of their mouths and their second antenna. The damage caused by movements, feeding and attachment of the parasites results in the appearance of necrotic alterations.

Destruction of the capillaries or deeper arteries of the gills cause constant hyperemia, resulting in a decrease in the number of erythrocytes, chronic anemia, iron deficiency and alteration in the haemoglobin ratio. These alterations depend on the time length of infestation and the extent of damage to the gill filaments.

Prolonged action of the pathogenic factor results in an impairment to haematopoietic function, and an oxygen deficiency in the tissue which intensifies, resulting in subsequent metabolic disturbances, impairing the activity of the organism. Among the problems caused, there is a visible insufficiency in the development of the reproductive organs.

NATARAJAN \& FELIX (1987) observed in Mystus gulio Merza, 1975 contaminated by various parasites, including Ergasilus sp., a drastic reduction of $\mathrm{Er}, \mathrm{Hb}$ and $\mathrm{Ht}$, with an elevation in $\mathrm{MCV}, \mathrm{MCH}$ and $\mathrm{MCHC}$ as compared to the noninfested fish. In the beginning of the infestation there was an increase in the values of the blood parameters. In terms of both total count and relative ratios, more lymphocytes were found in infested fish and more granulocytes in noninfested ones.

The leeches, besides provoking lesions and anemia by their own feeding, are vectors of haemogregarines and trypanosomes (KHAN 1985; PULSFORD 1984). However, KIRMSE (1980) thinks that the leeches transmit trypanosomes and that the haemogregarines are transmitted by copepods, isopods or blood-feeding monogeneans.

Although in the present study leeches were not found on every Mugil platanus infested by trypanosomes or haemogregarines, they were found on $16.72 \%$ of the fish (Tab. I). Lesions at the edges of the fins suggest places of leech attachment. Attached leeches may have disattached themselves when the fish were captured.

The few studies of leeches that feed on mullets are cited by PAPERNA \& OVERSTREET (1981) and none of these refer to alterations in the blood provoked by these parasites.

It is also necessary to keep in mind that the alterations in blood characteristics 
could be due to endogenous conditions of the fish. In this case it becomes difficult to distinguish between the effects of other variables; age, size, maturity, the environment in which the fish live, and those of parasitism.

\section{CONCLUSION}

Parasitism, in the degree found in this study, does not influence the studied blood parameters of Mugil platanus in natural conditions.

ACKNOWLEDGEMENTS. Thanks go to laboratory technicians Jose Plaza and Helio Sanches Mariscal, for their valuable collaborations in the collections of the fish and to graphic artist Regina Celia Barbosa da Silva, who drew the graphs. An IP-SAA/SECIRM joint project.

\section{REFERENCES}

BECKER, C.D. 1970. Haematozoa of fishes, with emphasis on north american records. A Symposium on diseases of fishes and shellfishes, American Fisheries Society, 5: 82-100.

BLAXHALL, P.C. 1972. The haematological assessment of the health of freshwater fish. Jour. Fish Biol. 4: 593-604.

Carnevia, D.; R. Mazzoni; O. Areosa; T. Eastman \& D. Lorenzo. 1988. Variaciones estacionales de diversas parasitosis en la lisa Mugil liza Val. 1836 del Rio de la Plata. Anais VI Simpósio Latinoamericano de Aquicultura, Associação Brasileira de Aqüicultura, Florianópolis, p. 299-304.

Collier, H.B. 1944. The standardization of blood haemoglobin determinations.

Can. med. Ass. Jour. 50: 550-552.

ConRoY, G.; D.A. ConRoY. 1984. Diseases and parasites detected in Grey Mullets (Mugilidae) from coastal waters of São Paulo State, Brasil. I. Adult silver mullet (Mugil curema Val. 1836). Revta Ita. Piscic. Ictiop. 19 (1): 14-28.

Costa Neto, P.L. 1977. Estatística. São Paulo, Edgard Bluncher, 246p.

CotTrell, B.J. 1977. A trypanosome from the plaice, Pleuronectes platessa, L. . Jour. Fish Biol. 11 (1): 35-47.

EINSZPORN-ORECKA, T. 1970. Quantitative changes in the circulating blood of tench (Tinca tinca (L.) infested by Ergasilus sieboldi Nordm. Pol. Arch. Hydrobiol. 17 (30/4): 463-481.

EIRAS, J.C. 1987a. Detection of Haemogregarina bigemina (Protozoa: Apicomplexa) infection in fish erythrocytes by phase-contrast microscopy. Jour. Fish Biol. 31 (2): 291-292.

- 1987b. Occurence of Haemogregarina bigemina (Protozoa: Apicomplexa) in Blennius pholis (Pisces: Blenniidae) along the Portuguese west coast. Jour. Fish Biol. 30 (5): 597-603.

FACCHINI, B.H. 1987. Estudos hematológicos sobre Mugil liza Cuvier \& Valenciennes e Mugil curema Cuvier \& Valenciennes da região estuarino lagunar de Cananéia - $\mathbf{2 5}^{\circ} 1$ 'S - Brasil. $\mathrm{PhD}$. Thesis, unpublished, Instituto de Biociências, 159p. 
Goldenfarb, P.B.; F.P. Bowyer; E. Hall \& E. BRosius. 1971. Reproducibility in the hematology laboratory: the microhematocrit determination. Amer. Jour. Clin. Path. 56 (1): 35-39.

HARVEY, W.R. 1987. User's guide for LSMLMW: Mixed model-version. Ohio State University, 59p.

ISAAC-NAUM, V.J. \& A.E.A.M. VAzZOLLER. 1983. Biologia reprodutiva de Micropogonia furnieri (Desmarest, 1823) (Teleostei, Scianidae). 1. Fator de condição como indicador do período de desova. Bol. Inst. Oceanogr. 32 (1): 63-69.

KHAN, R.A. 1977. Blood changes in the Atlantic cod (Gadus morhua) infected with Trypanosoma murmanensis. Jour. Fish. Res. Bd. Can. 34: 2193-2196.

. 1985. Pathogenesis of Trypanosoma murmanensis in marine fish of northwestern Atlantic following experimental tranmission. Can. Jour. Zool. 63: 2141-2144.

KHAN, R.A.; J. CAMPBELL \& M. BARRET. 1980. Trypanosoma murmanensis: its effect on the longhorn sculpin, Myoxocephalus octodecemspinosus. Jour. Wildl. Dis. 16: 359-361.

KinKELIN, P. DE; CH. MiCheL \& P. GHITINO. 1991. Tratado de las enfermedades de los peces. Zaragoza, Acribia S.A., 353p.

KIRMSE, P. 1980. Observations on the pathogenicity of Haemogregarina sachai Kirmse, 1978, in farmed turbot Scophthalmus maximus (L.). Jour. Fish Dis. 3: 101-114.

LETCH, C.A. \& S.J. BALL. 1979. Prevalence of Trypanososma cobitis Mitrophanow, 1833 in fishes from the River Lee. Parasitology 79: 119-124.

Natarajan, P. \& S. Felix. 1987 Studies on infestation and effects of certain parasites of Mystus gulio along the south-east coast of India. Aquaculture 67: 233-235.

PAPERNA, I. \& M. LAHAV. 1974. Mortality among grey mullets in a seawater pond due caligiid parasitic copepod epizootic. Bamidgeh 26 (1): 12-15.

PAPERNA, I.; R.M. OverstreEt. 1981. Parasites and diseases of mullets (Mugilidae), p.411-493. In: O.H. Oren (Ed.). Aquaculture of grey mullets. Cambridge, Cambridge Univ. Press, 507p.

Pavanelli, G.C. \& M.H.M. Santos. 1991. Proteocefalídeos parasitos de peixes, em especial Pimelodídeos, do Rio Paraná. Revta Unimar 13 (2): 163-175.

PUlSFORD, A. 1984. Preliminary studies on tripanosomes from the dogfish, Scyliarhinus canicula L. Jour. Fish Biol. 24 (6): 671-682.

RoBerTS, R.J. 1981. Patologia de los Peces. Madrid, Mundi-Prensa, 366p.

Scorvo Filho, J.D.; E.R. Almeida-Dias; L.M.S Ayroza \& P.F.C. Novato. 1992. Efeito da densidade sobre o desenvolvimento de alevinos de tainha listrada (Mugil platanus) em água doce. Bol. Inst. Pesca 19: 105-109.

SMIRNOVA, L.I. 1971. Pathology of carp blood infested by haemogregarina. Hidrobiologia 37 (1): 1-6.

TATCHER, V.E. 1981. Patologia de peixes da Amazônia brasileira, 1. Aspectos gerais. Acta Amazonica 11 (1): 125-140. 
TORT, L.; J.J. WATSON \& I.G. PRIEDE. 1987. Changes in in vitro heart performance in rainbow trout, Salmo gairdneri Richardson, infected with Apatemon gracilis (Digenea). Jour. Fish Biol. 30 (3): 341-347.

WiNTROBE, M.M. 1934. Variations in the size and hemoglobin content of erythrocytes in the blood of various vertebrates. Folia Haematologica 51: 32-49.

Recebido em 30.XI.1995; aceito em 10.VI.1997. 